DOI: $10.14746 / \mathrm{amp} .2016 .21 .8$

WOJCIECH KOWAL

Saint Paul University, Ottawa

\title{
Personal Parish As An Element Of The Organizational Structure Of The Pastoral Care Of Polish Immigrants By The Missionary Oblates Of Mary Immaculate In The Archdiocese Of Toronto
}

The topic chosen for this article could easily merit something of the scope of a monograph rather than a short paper. Therefore, this presentation cannot, and by no means will, attempt to respond to all the questions related to personal parish as an element of the organizational structure of the pastoral care of Polish immigrants in Toronto, Canada. The article will rather offer a canonist's look at the reality which has multiple and diverse aspects. Moreover, the ambit of this reflection will be limited to the Polish personal parishes presently entrusted in the Archdiocese of Toronto to the Missionary Oblates of Mary Immaculate, a religious clerical congregation of pontifical right serving the Church in Canada since 1841.

\section{The Past: Personal Parish in Church's Legislation before the 1983 Code of Canon Law}

When referring to personal parishes, one has to go back to the 1917 Code of Canon Law or even to an earlier Church legislation. The Pio-Benedictine Code required that all dioceses be divided into parishes:

Can. 216, §1 - The territory of each diocese shall be divided into distinct territorial parts; to each part is assigned its own church with a determined people, and its own rector, as its proper pastor, is to be put in charge for the necessary care of souls (Sources/Codex iuris canonici). ${ }^{1}$

${ }^{1}$ All references to the canons of the 1917 Code will be styled „CIC/17, c.” for canon and „IC/17, cc.” for canons, followed by the canon number(s). 
The same canon, in $\S 4$, foresaw the creation, with a necessary indult from the Holy See, of non-territorial parishes for persons speaking various national languages or belonging to a specific nation, living in the given city or territory. Similarly, no change regarding such parishes already in existence was possible without consultation with the same authority.

On May 20, 1923, the Pontifical Commission for the Authentic Interpretation of the Canons of the Code determined that this discipline was applicable also to cases of establishing a parish which was destined exclusively for the faithful of one of the official languages in a state where multiple official languages were used (151).

One of the commentaries to the $C I C / 17$ brought in a distinction between ,[a] personal parish [which] is one without territorial limits, having pastor and its church, and a definite population determined by personal qualities alone without respect to territory; for example, people of a certain clan or family" and ,[a] mixed parish (partly territorial and partly personal) [...] whose population is determined by both territorial and personal criteria; for example, all Italians within a certain territory" (Bouscaren, Ellis, and Korth 150). In the present terminology both would be considered personal parishes, while the term „mixed” would rather be employed to signify a parish which, at the same time, is territorial and personal (Wiatrowski 133). As a contribution to the discussion on the possibility of having a parish which is at the same time territorial and personal, one could refer to the reply from the Pontifical Commission for the Authentic Interpretation of the Canons of the Code (Reply 151):

Whether, in regions of mixed tongue which politically constitute a single State, but where various so-called official languages are used, c. 216, §4, requires an apostolic indult for the erection of a parish which is destined exclusively for the faithful of a certain language, even if that language be one of the official ones, and even if the parish to be so erected have its own distinct part of the territory of the diocese [emphasis added] (et paroecia erigenda suam distinctam habeat partem territorialem in dioecesi).

It seems that the question hints on a possibility of having a ,mixed" parish whose territory would be distinct from any other territorial parish in a diocese (suam distinctam habeat partem territorialem in dioecesi), and the reply does not take an issue with that presupposition.

The act of erection of a parish needs to be distinguished from the act of entrusting it to a religious congregation for the purposes of exercising pastoral care of the given community. For uniting a parish pleno iure to a religious house (a moral person), an indult from the Holy See was again necessary (Bouscaren et al. 865; Ciesluk passim). In such a case, while the moral person was the habitual pastor (parochus), the actual care of souls was the responsi- 
bility of a priest, called vicar (vicarius) (see CIC/17, c. 452, §1; cf. Bouscaren et al.). Nevertheless, it was always possible, again with an indult from the Holy See, to entrust the parish to a religious community of clerics without this arrangement being a union pleno iure (Wernz 446). As the canonical basis for the need of an indult, Wernz seems to indicate the apostolic constitution Romanos pontifices of Leo XIII. ${ }^{2}$ This was the option that was chosen by bishops of the Archdiocese of Toronto, entrusting Polish personal parishes to the Oblates on the basis of particular agreements.

Immigration of the Poles to Canada on a large scale began in 1858, with the first group of Kaszubi who settled in the region of Madawaska, ON, including Barry's Bay, Wilno, Round Lake. From the end of the XIX ${ }^{\text {th }}$ century until the beginning of the First World War there was a wave of immigrants coming from Wielkopolska, and later from Galicia; the number of newly arrived immigrants reached some 60000 persons. Between the two World Wars some 45000 Poles arrived to settle in Canada. After the Second World War, in the years 1946-1952, some 55000 new Polish immigrants, mostly categorized as „displaced persons” found their new home in Canada. Between 1953 and 1980 Canada received some 63000 Polish immigrants, while in 1981-1991, in good measure due to the introduction of martial law in Poland (1981-1983) and ensuing persecution of the Solidarity movement members, 80000 Poles arrived. The last major influx of Polish immigrants took place in 1991-1996, totaling 35000 people (Reczyńska 16-18).

The metropolitan region of Toronto is the place in which the great majority of persons of Polish origin has settled. This has been acknowledged already in 1935 when the first Polish Oblates started to work in Toronto: Fr. Stanisław Puchniak had been assigned as parish priest to an already existing parish of Saint Stanislaus in Toronto. He arrived there on 29 June (Błażejak, „Współczesne zaangażowanie...” 74; A Half a Century 67-68). In 1940, on the request of Archbishop McGuigan, the Oblates provided the personnel for Saint Mary's Parish, with Fr. Piotr Klita becoming the first Oblate pastor. However, the parish history goes back to the year 1914. It was established under the title of The Nativity of the Blessed Virgin Mary, with property purchased by December 1, 1914 (Błażejak „Współczesne zaangażowanie...”, 77; A Half a Century 70-71). The Oblates left the parish on November 23, 2008, on the Solemnity of Christ the King, after they had assured the celebration of the Mass on Sunday in Polish until the beginning of June, 2009. ${ }^{3}$

In 1948, Saint Casimir Parish was created, starting with the construction of a parish hall, later completed with building of the church. Its solemn blessing

\footnotetext{
2 Sources/Leo XIII.

3 Sources/Błażejak, Letter to Msgr. Marco Laurencic.
} 
took place on May 23, 1954 (Błażejak „Współczesne zaangażowanie...,” 75; A Half a Century 80-81). The indult of the Sacred Congregation of the Council, March 24, 1949, no. 8572-48 indicates that Saint Stanislaus Parish was divided and from its part Saint Casimir parish was created. ${ }^{4}$

On July 12, 1949, the canonical situation of the Oblates serving in Polish personal parishes was determined in particular agreements between the Archdiocese and the Oblate Congregation. James Charles Cardinal McGuigan, Archbishop of Toronto, acting with prior consent of the college of consultors and in virtue of the indult of the Sacred Congregation of the Council of March 24, 1949, prot. no. 8571/48, and Fr. Bernard Ueberberg, OMI, Provincial of Saint Mary of Regina, with prior consent of his provincial council and the authorization of the Superior General signed an agreement by which the Archbishop of Toronto entrusted two Polish national parishes, of Saint Stanislaus and of Saint Casimir , ,...] situated in Toronto, to the Province of Saint Mary of Regina of the Congregation of the Missionary Oblates of Mary Immaculate, which accepts the parish to exercise authority over it in spiritual as in temporal matters, in perpetuity at the disposition of the Holy See (ad nutum Sanctoe Sedis) in accordance with the norms of canon law, while observing the Constitutions of the Oblates and the provisions of the present agreement.".

Due to the fact of the existence of several Polish national parishes in the Archdiocese of Toronto, the agreements specify the parameters of the pastor's jurisdiction: ,,[...] the [...] pastor has the integral pastoral care of one and all the people of Polish extraction or language, and of all institutions and churches belonging to the same people, to be exercised according to the norm of canon law, with the exclusion from the jurisdiction of the said pastor people of other extraction or language, even if they dwell within the limits of his territory" (Conventio circa paroeciam a Sancto Stanislao, no. 3, §1, p. 2, and Conventio circa paroeciam a Sancto Casimiro, no. 3, §1, p. 2). The territory is therefore specified in the contracts, as a secondary determinant of the community of the faithful entrusted to the said pastors. For Saint Stanislaus Parish the territory was delimited in the following way: the northern border was Bloor Street, the eastern border coincided with the City of Toronto limits, in the South, Lake Ontario set the limit, and in the West, the corner of Bloor and Dufferin Street, Bloor Street West, and Dufferin North (Conventio circa paroeciam a Sancto Stanislao, no. 2, §1, p. 2.) For Saint Casimir Parish, the northern border was Bloor Street, the eastern, Dufferin Street, in the South, the City border or the shore of Lake Ontario set the limits, while in the West, the territory extended

${ }^{4}$ Sources/Sacred Congregation of the Council.

5 Sources/Conventio circa paroeciam a Sancto Stanislao; Sources/Conventio circa paroeciam a Sancto Casimiro. 
„outside of the City up to Humber River" (Conventio circa paroeciam a Sancto Casimiro, no. 2, §1, p. 2).

There was a further determination, no. $3, \S 2$ in both of those agreements: „Polish families accustomed to English may, however, freely choose to remain as members of the territorial parishes in whose limits they live." This was rather a logical conclusion on the basis of the law on domicile (see $C I C / 17$, c. 92, $\S 1)$ and not a matter of their choice: a residence within the territory of a given parish, with the intention of remaining there indefinitely (cum animo ibi perpetuo manendi) would bring up on the acquisition of a domicile in that parish. In fact, the history of personal ecclesial structures in North America reveals a certain tension (which may also present itself today) regarding especially the immigrants' children who apparently were not keen to continue as members of their parents' personal parishes. Indeed, on January 15, 1938, the Sacred Congregation of the Council declared for the territory of the USA that:

When foreign immigrants and their children speak the English language and do not wish to belong to their own national parishes, they must affiliate with the American territorial parish in which the said immigrants and their children have their domicile, and not with any other parish in which the English language may be spoken (Cicognani 79-80).

An interesting stipulation regarding the jurisdiction of the pastors of Saint Stanislaus and Saint Casimir parishes concerns the spiritual care of ,,[... all institutions and churches belonging to the same people" (Conventio circa paroeciam a Sancto Stanislao, no. 3, §1, p. 2, and Conventio circa paroeciam a Sancto Casimiro, no. 3, §1, p. 2). This referred principally to schools and Polish organizations which routinely requested appointment of the Polish clergy as chaplains in accordance with their internal regulations.

To complete the picture of the parish pastoral work of Assumption Province in the Archdiocese in Toronto, one has to mention another parish entrusted to Assumption Province, that of Holy Angels, a territorial parish, but serving also the needs of Italians and Poles of a larger area. The authorization of the General Administration to proceed with the process of acquiring this new parish was granted on August 27, 1956, as stated in the letter of J. Walsh, OMI, assistant general, to Fr. Michael J. Smith, Provincial of Assumption Province (Michalski 62). Fr. Smith requested from the General Administration permission to accept a new parish on September 6, 1960. ${ }^{6}$ On the other hand, Godfrey W. Kuckartz, Assistant General, in a letter of January 12, 1967 to Fr. Feliks Kwiatkowski, Provincial of Assumption Province mentions that the

\footnotetext{
${ }^{6}$ Sources/Smith, Letter to the General Administration.
} 
General Administration authorized the negotiations in this regard with Cardinal McGuigan on October 3, 1960 (Kuckartz, no. 1). There was no record in the files of a formal contract with the Archdiocese (Kuckartz, no. 4). ${ }^{7}$

Fr. Michael Smith, in a letter of July 26, 1960, suggested to Archbishop McGuigan that the Oblates could provide personnel, Italian and Polish speaking, for a prospective new parish in the vicinity of the already existing Holy Angels School. ${ }^{8}$ Getting Italian Oblates for the new parish proved to be a difficult task over time as it is witnessed by the correspondence between Assumption Province and the General Administration. The parish was accepted by Assumption Province in the Fall of 1960.

The Oblates of Assumption Province have also been entrusted with pastoral care of Saint Hedwig Parish in Oshawa. On August 23, 1952, a group of Poles: Józef Halik, Stanisław Borek, Antoni Gwóźdź and Jan Ściuk, sent a letter to Card. James McGuigan, requesting the presence of a Polish priest in Oshawa (Kalendarium Parafii Św. Jadwigi i Polonii 6; Wotum Polonii w Oshawie 17). On October 12, 1952, Fr. Peter Klita, OMI, who on September 1, 1952 was appointed chaplain of the community of the Felician Sisters in Oshawa, celebrated the first Mass for the Polish community there and the corner stone for the new church was laid by James Card. McGuigan, on October 17, $1954 .{ }^{9}$ The Missionary Oblates of Assumption Province left the parish in 1979: on October 12, 1979 the parish was entrusted to the Society of Christ Fathers (Society of Christ for Poles Living Abroad; Towarzystwo Chrystusowe dla Polonii Zagranicznej) (Kalendarium Parafii Św. Jadwigi i Polonii 71).

The Oblates of Assumption Province have also served in Saint Catherine of Siena Parish, Toronto, which they renounced, due to the lack of personnel (there were only two Italian Oblates left in the Province) in June of $1992 .{ }^{10}$

\section{The Present: The Status of Personal Parishes According to the 1983 Code of Canon Law}

It seems entirely appropriate to recall John Paul II who spoke of the importance of the parish:

The ecclesial community, while always having a universal dimension, finds its most immediate and visible expression in the parish. It is there that the Church

\footnotetext{
${ }^{7}$ Sources /Kuckartz.

${ }^{8}$ Sources/Smith, Michael J., Letter to James Charles Cardinal McGuigan.

9 See Sources/Codex Historicus.

10 See Sources/Pulchny [Holy Angels].
} 
is seen locally. In a certain sense it is the Church living in the midst of the homes of her sons and daughters (Christifideles laici no. 26).

I find these words especially helpful in stressing the need, not always however perceived by diocesan bishops in North America, to offer new immigrants a possibility to hear the Gospel, to celebrate the sacraments, to pray together in the language and according to the customs evolved in the cultural setting which they hold dear to their hearts.

The norm of $C I C / 17$, c. $216, \S 4$ restricted the right of the diocesan bishop to establish personal, national or linguistic parishes without an indult of the Holy See, or to make any modification in those already established without consulting the same authority. In the new Code of Canon Law, the principle that a parish is, as a general rule, territorial is maintained, but the diocesan bishop can make exceptions wherever this is useful (ubi vero id expediat, see c. $515, \S 2)$.

Following the insight from the Second Vatican Council, the current legislation provides the following description of parish:

http://prezydent2015.pkw.gov.pl/326_Wyniki_zagranica/4Can. $515 \S 1^{11}$ - A parish is a certain community of the Christian faithful stably constituted in a particular church, whose pastoral care is entrusted to a pastor (parochus) as its proper pastor (pastor) under the authority of the diocesan bishop (Sources/Code of Canon Law).

Decree on the Pastoral Office of Bishops in the Church Christus Dominus, no. 23, 3 takes into account spiritual needs of persons of various languages and nationalities, present on a given territory:

Likewise in similar circumstances provision should be made for the faithful of a different language group either by appointing priests who speak that language, or by creating special parishes, or by appointing an episcopal vicar well versed in it. If it is deemed suitable, he may be ordained bishop, or the matter may be dealt in some other appropriate way.

Canon 518 can be considered an application of this conciliar directive, and, while stressing the fundamental criterion of territoriality of a parish, offers a description of personal parish:

11 The following documents are listed as the conciliar sources of c. 515, $\S$ : Constitution on the Sacred Liturgy Sacrosanctum concilium, no. 42, Dogmatic Constitution on the Church Lumen gentium, no. 26, Decree on the Pastoral Office of Bishops in the Church Christus Dominus, no. 30, Decree on the Apostolate of Lay People Apostolicam actuositatem, no. 10, and Decree on the Church's Missionary Activity Ad gentes, no. 37. 
Can. $518^{12}$ - As a general rule a parish is to be territorial, that is, one which includes all the Christian faithful of a certain territory. When it is expedient, however, personal parishes are to be established determined by reason of the rite, language, or nationality of the Christian faithful of some territory, or even for some other reason.

While c. 518 states the general rule of the territorial character of parishes, canon $515 \S 1$ emphasizes the fact that the parish is a part of the particular church not primarily in the geographical sense, ${ }^{13}$ but is a specific community of the faithful. Nevertheless, the territorial aspect of personal parish has not been set aside by the new Code: the territory serves as the secondary determinant of a given portion of the people of God.

No longer an indult of the Holy See is required for a diocesan bishop to erect or to modify personal parishes. That greatly facilitates the task of diocesan bishops to provide for the needs of the faithful in their particular churches. Moreover, the diocesan bishop can entrust a parish to a clerical religious institute or clerical society of apostolic life without any need of the Holy See's intervention.

The new norms could be seen at work in recent examples of the involvement of Assumption Province in the pastoral care of Polish speaking Catholics in the Archdiocese of Toronto. A steady growth of the Polish population in the City of Mississauga, ON, called for extending the boundaries of the existing pastoral care west of the City of Toronto. On October 15, 1979, Fr. Stanley Bąk was appointed pastor (installed on December 2, 1979, by Archbishop Philip Pocock) for a six year term, of a new Polish personal parish in Mississauga. The same letter of appointment approves the title of the parish, namely Blessed Maximilian Kolbe. ${ }^{14}$

The most recent new personal Polish ecclesiastical circumscription ${ }^{15}$, entrusted to Assumption Province in the Archdiocese of Toronto on 31 July 1998 is Saint Eugene de Mazenod Mission in Brampton (Our history). A memorandum of auxiliary bishop of Toronto, Terrence Prendergast, SJ, of May 6, 1998 indicated the needs of a growing Polish community in Brampton. The Polish people approached him ,with their hopes for a new parish and church.” The Archdiocese preferred ,establishing in southwest Brampton [...] a filial

12 The following are listed among the sources of c. 518 : $C I C / 17$, c. $216, \S \S 1,2$, and 4; Reply May 20, 1923; Christus Dominus no. 23; Ecclesiae Sanctae, I, nos. 21 and 13; Directory on the Pastoral Ministry of Bishops no. 174.

${ }^{13}$ In some civic jurisdiction, like State of Louisiana and City of Winnipeg (Canada), territorial divisions are called ,parishes.”

14 Sources/Carter.

15 Sources/Agreement. 
(daughter) church or mission within the pastoral scope and responsibilities of the parish of St. Maximilian Kolbe - the patron proposed for the new entity is St. Eugene de Mazenod." 16 This corresponds with a request of the provincial of Assumption Province, Chris Pulchny, OMI, that ,the Archdiocese officially recognize the Brampton community as a mission in the Archdiocese and appoint the present pastor of St. Maximilian Kolbe Church as the administrator of this mission." 17 Eventually, Cardinal Aloysius Ambrozic, Archbishop of Toronto decided to ,establish a personal quasi-parish in the form of a Mission with the Care of Souls for the Catholic faithful of the Polish community to be known as St. Eugene de Mazenod - Mission. The territory of the Mission shall be Brampton, Ontario, the western pastoral region of the Archdiocese, specifically Peel Region, North of Hwy. 407, but excluding Mississauga, Ontario."18

The precise canonical status of Saint Eugene Mission is an interesting question. The decree of erection points to , a personal quasi-parish in the form of a Mission with the Care of Souls." 19 On the other hand, the memorandum of May 6, 1998 mentioned the intention of the Archdiocese to move towards creating a mission attached to an existing parish (Saint Maximilian Kolbe). It seems, nonetheless, that the new entity is in fact a quasi-parish, as it is determined by the territory which does not coincide with the territorial limits of Saint Maximilian Kolbe Parish in Mississauga and the pastor has the same rights and obligations as ,every pastor [parish priest] [...] according to the law of the Church." It is interesting to note the broad faculties of pastor of Saint Eugene de Mazenod Mission: „Within the limits of the territory of the Mission, the Pastor by virtue of his office validly assists at the marriage not only of his subjects, but also of non-subjects, provided one or other of the parties is of the Polish community.” ${ }^{20}$ Indeed, c. $516 \S 1$ stipulates that: „Unless the law provides otherwise, a quasi-parish is equivalent to a parish; a quasi-parish is a definite community of the Christian faithful in a particular church, entrusted to a priest as its proper pastor but not yet erected as a parish because of particular circumstances." The canon does not state that the priest in charge of a quasi-parish is equivalent to the parish priest, nevertheless, it can be argued that if the quasi-parish is equivalent to a parish, the priest in charge should have powers and faculties equivalent to those of the parish priest. On the other hand, an ethnic-linguistic mission would rather be ,identified with [an already existing local] territorial parish which, with the help of one or more pastoral workers, would take care of one or more groups of immigrant faithful. The

16 Sources/Prendergast.

17 Sources/Pulchny, Letter to Rev. K. John Murphy.

18 Sources/Ambrozic.

19 Ibid. Cf. c. 516.

${ }^{20}$ Sources/Ambrozic. 
chaplain [of the mission] would be part of the parish team." ${ }^{21}$ As yet, Saint Eugene de Mazenod Mission was not erected as parish; nevertheless, the priest in charge is styled ,pastor of the mission of St. Eugene de Mazenod"22 and has all the powers and faculties of parish priest (regarding the prerogatives of the mission's pastor, the contract for the mission in Brampton simply copies the text of the new agreements with regard to Saint Stanislaus, Saint Casimir and Saint Maximilian parishes in what concerns their pastors' duties). ${ }^{23}$

Indeed, in the recent time, Assumption Province negotiated/renegotiated several of its agreements concerning parishes entrusted to the Oblates by diocesan bishops across Canada. The existing structure of Polish personal parishes is upheld in the Archdiocese of Toronto and it finds its reflection in recently signed contracts between Assumption Province and the Archdiocesan authority. And thus contracts concerning Saint Stanislaus and Saint Casimir parishes were extended, albeit with certain modifications, and other contracts, concerning Holy Angels and Saint Maximilian Kolbe ${ }^{24}$ parishes were formalized and signed by Thomas Cardinal Collins, Archbishop of Toronto, and Rev. Marian Gil, Provincial Superior of Assumption Province of the Missionary Oblates of Mary Immaculate on 2 May, 2014. ${ }^{25}$ These agreements respond to the norm of c. 520 which calls for entering into contracts between the diocesan bishop and the competent superior of a religious congregation, with specifying such elements as the duration of the agreement (in perpetuity or for a determined number of years), the number of priests and other personnel to be assigned to the parish, their rights and responsibilities, the work to be accomplished, financial considerations, and provisions for termination of the agreement.

21 Sources/Erga migrantes caritas Christi no. 91. One can agree that the decree of July 31 , 1998 is formulated in a way that leaves space for some uncertainties regarding the precise ecclesiastical status of Saint Eugene de Mazenod Mission.

22 Sources/Agreement, no. 2, §1, p. 2.

23 The decree of appointment of Fr. Adam Filas, OMI as ,pastor of St. Eugene de Mazenod Mission, Brampton" by Cardinal Thomas Collins, Archbishop of Toronto, bears the date of November 21, 2012. The date of installation of the pastor was set for January 1, 2013 and his authority extends to ,the full pastoral care of that community with all the faculties, duties, rights and privileges according to the norms of law". See Sources/Collins.

24 In the Archives of Assumption Province of the Missionary Oblates of Mary Immaculate, Toronto, there is a text of a contract entrusting Saint Maximilian Kolbe Parish to Assumption Province, with the accompanying rescript of the General Administration permitting the acceptance of a new parish (See Sources/Contract). The contract was for 25 years in duration, but there are no signatures on it. Fr. John A. Mazur, OMI, Provincial who was to be a signatory of the agreement on behalf of Assumption Province has no recollection, if the contract was in fact concluded. The Archdiocese of Toronto could not trace such a contract in their archives, either.

25 Kept in the Archives of Assumption Province of the Missionary Oblates of Mary Immaculate, Toronto, ON, under the respective parish files. 
Apart from formal structures of personal parishes, there were other forms in which Assumption Province provided pastoral care to Polish speaking Catholics throughout the Archdiocese of Toronto. In some (territorial) parishes Masses in Polish were celebrated, ${ }^{26}$ as for instance, at Saint Augustine of Canterbury Church, a Sunday Mass was celebrated beginning with the first Sunday of Advent of $1990 .^{27}$

\section{The Future: The Pastoral Care of Persons with Polish Ancestry in Canada}

Increasingly in the world today, because of migrations and socio-cultural changes, persons and groups of different languages and cultural traditions live within the same territory. Given the scale of this phenomenon, this situation creates for the Church some hitherto unknown challenges. As a consequence, the traditional notions of territoriality and personality take on a new importance within the context of canonical studies and pastoral/administrative practice. No wonder then, that the issue of territoriality versus personality of the organization of the structures of the Church receives quite a deal of attention in canonical circles nowadays (Territorialità).

Canon $383 \S 1$ of the 1983 Code stresses the obligation of the diocesan bishop as a pastor of his flock, ,[...] to show himself concerned for all the Christian faithful entrusted to his care, of whatever age, condition, or nationality they are, whether living in the territory or staying there temporarily; [...]." Indeed, immigrants, especially those who do not speak the language of the country in which they found themselves, fall into this category.

On May, 3, 2004, the Pontifical Council for the Pastoral Care of Migrants and Itinerant People issued the instruction Erga migrantes caritas Christi (the love of Christ towards migrants). In no. 91 it gives an outline of possible pastoral structures which correspond to a natural „life cycle" of immigrant communities within a local Church.

The first among the structures is the so-called missio cum cura animarum, which applies to ,[...] communities still being built up," including ,ethnic/national groups $[\ldots]$ that have not yet settled down." While this arrangement was used in Canada when the Polish Catholic community was not yet strong in numbers (the document calls it ,the classic formula” for the organization of

26 The auxiliary bishop of Toronto, Richard J. Grecco indicated on June 25, 2008 that Masses in Polish were celebrated in 12 parishes of the Archdiocese (with 37 different nationalities composing the Archdiocesan community). See Sources/Grecco.

27 See Sources/Pulchny [St. Mary]. 
the pastoral care of newly fledged immigrant communities), certainly, it does not respond anymore to the present reality.

The next level of organization consists of personal parishes:

[...] a personal ethnic-linguistic parish [...] is foreseen for places where there is an immigrant community that will continually have newcomers even in the future, and where that community is numerically strong. It maintains the typical characteristic service of a parish (proclamation of the Word, catechesis, liturgy, diakonia) and will be concerned above all with recent immigrants, seasonal workers or those coming by turns, and with others who for various reasons have difficulty in finding their place in the existent territorial structures (Erga migrantes no. 91).

The document points to the numeric strength of a given community, which extends into the future. But one has to notice that the document does not limit the necessary conditions for establishing/maintaining personal parishes to those related to the community of the faithful as such, but indicates the necessary aspects of the pastoral ministry in the parish, namely preaching in the language of the community, catechesis (which indirectly points to the availability of appropriate materials in a given language), access to approved liturgical books, and the availability of persons involved in various parish initiatives speaking the language and immersed in a given culture. Generally that would also include a certain closeness of the clergy serving the immigrants abroad to the Church in the nation at home - a spiritual link to be sure, as the structures of the pastoral care of the entire Church are organized in accordance with the territorial criterion.

Other forms of organization of the pastoral care of migrants indicated in the Instruction include a local, territorial parish with an ethnic-linguistic mission where one or more pastoral workers tend to a group of immigrant faithful or an ethnic-linguistic pastoral service on a zonal level, in the situation when immigrants who are already relatively well integrated in the local society (Erga migrantes no. 91).

Even though various structures for providing pastoral care for immigrants are foreseen in the Church's legislation, one can conclude that the parish, while not an essential structure in the Church is, nevertheless, a necessity of practical order. This does not mean, however, that similar qualification of necessity can be attributed to the existence of personal parishes.

A theological reflection on the parish reveals its primary role in bringing in the reality of the Church close to a person:

The parish is not principally a structure, a territory, or a building, but rather, „the family of God, a fellowship afire with a unifying spirit" [Lumen gentium, no. 21], „a familial and welcoming home” [Catechesi tradendae no. 67], the „community 
of the faithful" [can. 515, §1]. Plainly and simply, the parish is founded on a theological reality, because it is a Eucharistic community [Synod of Bishops, 1987, proposition 10]. This means that the parish is a community properly suited for celebrating the Eucharist, the living source for its upbuilding and the sacramental bond of its being in full communion with the whole Church. Such suitableness is rooted in the fact that the parish is a community of faith and an organic community, that is, constituted by the ordained ministers and other Christians, in which the pastor - who represents the diocesan bishop [Sacrosanctum concilium no. 42] - is the hierarchical bond with the entire particular church (Christifideles laici no. 26).

Even though the situation of new immigrants may be entirely different than of those Poles who were coming to Canada a century ago (new immigrants are better prepared to integrate into the new society due to their knowledge of languages, the level of education, or possession of professional skills in demand in the new country), nonetheless, there are also other factors - social, cultural, personal and emotional - which must be addressed in the new place of living. Also in living out their faith, the immigrants encounter numerous challenges, among them, new and unfamiliar Church structures and liturgical usages, and, in truth, the very understanding of the ecclesial community and the place of religion in the society.

A practical judgment follows that personal Church structures, including parishes, are still beneficial to immigrant population, and thus are worthy to be promoted, at least to respond to the needs of the first generation of immigrants. The counter argument, that the personal structures hamper integration of the newcomers with the local Church and the society at large can be questioned on the basis that it is not sufficiently theologically grounded - the immigrants are the local Church by their very presence in the particular (local) Church and their integration has rather a social and not theological character, while assimilation with the society and culture (certainly important some time ago) is not essentially the Church's role. One can expect, however, bearing any extraordinary circumstances that the situation of the Polish speaking community will face changing social realities: the personal parishes will encompass not only immigrants but also, and increasingly so, the persons born in Canada, though of parents who immigrated to Canada. That situation will inevitably bear on the judgments of diocesan bishops about the need for maintaining a particular personal parish. 


\title{
ABSTRACT
}

The article offers a particular perspective on the organizational structure of the pastoral care of Polish immigrants in Toronto, Canada. The scope of the presentation is limited to the Polish personal parishes in the Archdiocese of Toronto presently entrusted to the Missionary Oblates of Mary Immaculate (Assumption Province). The author's starting point is an analysis of the implementation of the concept of personal parish in the particular circumstances of the Archdiocese of Toronto, in the period of time before the Second World War when the first Polish personal parishes were formed. The canonical discipline allowed for creation, with the required indult from the Holy See, of non-territorial parishes for persons speaking various national languages or belonging to a specific nation living in the given city or territory. An important step in providing for solid organizational basis for pastoral care of Polish immigrants who in great numbers arrived in Canada after the Second World War, was taken with the signing on July 12, 1949 of particular agreements between the Archdiocese of Toronto and the Oblate Congregation entrusting two Polish national parishes, of Saint Stanislaus and of Saint Casimir, to the Oblates.. A new wave of Polish immigrants arriving in Canada in 1981-1991, due to the introduction of martial law in Poland, coincided with the promulgation of the new Code of Canon Law (1983) which greatly facilitated the task of diocesan bishops in providing pastoral care of immigrants through the means of personal parishes. As the metropolitan region of Toronto is the place in which the great majority of persons of Polish origin have settled, two new personal parishes, of Saint Maximilian Kolbe in Mississauga, ON and, most recently, of Saint Eugene de Mazenod in Brampton, ON were created. The author offers a canonical overview of the present situation after a recent renegotiation of canonical agreements between the Archdiocese of Toronto and Assumption Province of the Missionary Oblates of Mary Immaculate in Canada. Finally, a perspective for the future of pastoral care of persons with Polish ancestry in Canada is proposed. The author concludes that the personal Church structures, including parishes, are beneficial to immigrant population, and thus worthy to be maintained and promoted.

Keywords: Assumption Province, Canada; contract; Felician Sisters; immigrants; indult of the Holy See; jurisdiction; Oblates of Mary Immaculate; Archdiocese of Toronto; parish

Słowa kluczowe: Prowincja Wniebowzięcia, Kanada; kontrakt; imigranci; indult Stolicy Apostolskiej; jurysdykcja; Oblaci Maryi Niepokalanej; archidiecezja Toronto; parafia

\section{Abbreviations:}

\author{
AAS - Acta Apostolicae Sedis \\ ArchivesAP - Archives of Assumption Province of the Missionary Oblates of Mary \\ Immaculate, Toronto, ON
}




$\begin{array}{ll}\text { c. } & - \text { canon } \\ \text { cc. } & - \text { canons } \\ \text { CIC/17 } & - \text { Codex iuris canonici, } 1917 \\ \text { CLD } & - \text { Canon Law Digest } \\ \text { ON } & - \text { (Province of) Ontario } \\ \text { St. } & - \text { saint }\end{array}$

\section{BIBLIOGRAPHY}

\section{Sources}

Ad gentes. [Second Vatican Council. Decree on the Church's Missionary Activity. December 7, 1965]. AAS 1966:58, 947-990. English translation in: Vatican Council I: The Conciliar and Post-Conciliar Documents. Gen. ed. A. Flannery. Vol. 1. New rev. ed. Northport, NY: Costello Pub. Co., 1996. 813-856.

Agreement between the Ordinary of the Archdiocese of Toronto and the Provincial Superior of Assumption Province of the Missionary Oblates of Mary Immaculate concerning the mission of St. Eugene de Mazenod situated in the city of Brampton. ArchivesAP DOK St. Eugene de Mazenod - Brampton.

Ambrozic, Aloysius M. [Archbishop of Toronto]. Decree establishing a personal quasi-parish of St. Eugene de Mazenod in the form of a mission. July 31, 1998. ArchivesAP DOK St. Eugene de Mazenod - Brampton.

Apostolicam actuositatem. [Second Vatican Council. Decree on the Apostolate of Lay People. November 18, 1965]. AAS 1966:58, 837-864. English translation in: Vatican Council I: The Conciliar and Post-Conciliar Documents. Gen. ed. A. Flannery. Vol. 1. New rev. ed. Northport, NY: Costello Pub. Co., 1996. 766-798.

Błażejak, Janusz. Letter to Msgr. Marco Laurencic, Director of Priests' Personnel in the Archdiocese of Toronto. October 16, 2008, no. 250-2008. ArchivesAP DOE Toronto - St. Mary.

Carter, G.E. Decree of appointment of Fr. Stanley Bąk as pastor of Blessed Maximilian Kolbe parish. October 15, 1979. ArchivesAP DDD 1 - Archdiocese of Toronto.

Catechesi tradendce. [John Paul II. Post-synodal apostolic exhortation. October 16, 1979]. AAS 1979: 1277-1340. English translation in: Origins, 9 (1979-1980), 329-348.

Christifideles laici. [John Paul II. Post-synodal apostolic exhortation. December 30, 1988]. AAS 1989:81. 393-521. English translation: On the Vocation and the Mission of the Lay Faithful in the Church and in the World, Rome, Libreria editrice Vaticana, 1988.

Christus Dominus. [Second Vatican Council. Decree on the Pastoral Office of Bishops in the Church. October 28, 1965]. AAS, 1966:58. 673-696. English translation in: Vatican Council I: The Conciliar and Post-Conciliar Documents. Gen. ed. A. Flannery. Vol. 1. New rev. ed. Northport, NY: Costello Pub. Co., 1996. 564-590.

CIC/17 = Codex iuris canonici, Pii X Pontificis Maximi iussu digestus, Benedicti Papce XV auctoritate promulgatus, Typis polyglottis Vaticanis, 1917. English translation: The 1917 Pio-Benedictine Code of Canon Law. Ed. Edward N. Peters. San Francisco: Ignatius Press, 2001.

Code of Canon Law: Latin-English Edition, New English Translation. Prepared under the auspices of the Canon Law Society of America. Washington, DC: Canon Law Society of America, 1999.

Codex Historicus St. Hedwig's Parish. Archives of Assumption Province of the Missionary Oblates of Mary Immaculate, Toronto, ON.

Collins, Thomas [Cardinal Archbishop of Toronto], Decree of appointment of Fr. Adam Filas, OMI as pastor of St. Eugene de Mazenod Mission, Brampton. November 21, 2012. ArchivesAP DOK St. Eugene de Mazenod - Brampton. 
Contract entrusting Saint Maximilian Kolbe Parish to Assumption Province (an unsigned proposal). ArchivesAP DDD 1 - Archdiocese of Toronto.

Conventio circa paroeciam a Sancto Casimiro. Conventio inter Ordinarium Archidioecesis Torontinae et Superiorem Provinciae a Sancta Maria de Regina Oblatorum B.M.V. Immaculatae circa paroeciam a Sancto Casimiro in civitate Torontina sitam curis Oblatorum praedictae Provinciae in perpetuum ad nutum Sanctae Sedis commissam. July 12, 1949. ArchivesAP DOD Toronto St. Casimir.

Conventio circa paroeciam a Sancto Stanislao. Conventio inter Ordinarium Archidioecesis Torontinae et Superiorem Provinciae a Sancta Maria de Regina Oblatorum B.M.V. Immaculatae circa paroeciam a Sancto Stanislao in civitate Torontina sitam in perpetuum ad nutum Sanctae Sedis commissam. July 12, 1949. ArchivesAP DOC Toronto - St. Stanislaus.

Directory on the Pastoral Ministry of Bishops. [Sacred Congregation for Bishops. 22 February 1973]. Ottawa: Canadian Conference of Catholic Bishops, 1974. [to jest wydane w formie ksiazkowej]

Ecclesiae Sanctae. [Paul VI. Norms for Implementing the Decrees Christus Dominus and Presbyterorum ordinis. August 6, 1966]. AAS 1966:58. 757-775. English translation in: Vatican Council I: The Conciliar and Post-Conciliar Documents. Gen. ed. A. Flannery. Vol. 1. New rev. ed., Northport, NY: Costello Pub. Co., 1996. 591-610.

Erga migrantes caritas Christi. [Pontifical Council for the Pastoral Care of Migrants and Itinerant People. May 3, 2004]. AAS 2004:96. 762-822. English translation in: L'Osservatore Romano. English ed. May 26, 2004. Special insert, I-XVI.

Grecco, Richard J. [auxiliary bishop of Toronto]. Letter to Helena Ezman. June 25, 2008. ArchivesAP DOE Toronto - St. Mary.

Kuckartz, Godfrey W. [Assistant General]. Letter to Fr. Feliks Kwiatkowski, Provincial of Assumption Province. January 12, 1967. ArchivesAP DOF Toronto - Holy Angels.

Lumen gentium. [Second Vatican Council. Dogmatic Constitution on the Church. November 21, 1964]. AAS 1965:57. 5-75. English translation in: Vatican Council I: The Conciliar and Post-Conciliar Documents. Gen. ed. A. Flannery. Vol. 1. New rev. ed. Northport, NY: Costello Pub. Co., 1996. 350-426.

Prendergast, Terrence [auxiliary bishop of Toronto]. Memorandum. May 6, 1998. ArchivesAP DOK St. Eugene de Mazenod - Brampton.

Pulchny, Chris. [Holy Angels]. Letter to Aloysius M. Ambrozic, Archbishop of Toronto. November 26, 1990. ArchivesAP DOF Toronto - Holy Angels.

Pulchny, Chris. [St. Mary]. Letter to Aloysius M. Ambrozic, Archbishop of Toronto. November 26, 1990. ArchivesAP DOE Toronto - St. Mary.

Pulchny, Chris. Letter to Rev. K. John Murphy [chancellor of the archdiocesan curia in Toronto]. October 4, 1995, no. 236-95. ArchivesAP DDB - Provincial's correspondence.

Reply. May 20,1923. [Pontifical Commission for the Authentic Interpretation of the Canons of the Code]. AAS 1924:16. 113. English translation CLD. Vol. 1: 151.

Romanos pontifices. [Leo XIII]. Acta Sanctae Sedis. 1880:13. 481-498. English translation in The Tablet, May 21, 1881. 834-38.

Sacred Congregation of the Council. Indult no. 8572-48. March 24, 1949. ArchivesAP DDD 1 Archdiocese of Toronto.

Sacrosanctum concilium. [Second Vatican Council. Constitution on the Sacred Liturgy.

Smith, Michael J. Letter to James Charles Cardinal McGuigan, Archbishop of Toronto. July 26, 1960. ArchivesAP DOE Toronto - St. Mary.

Smith, Michael J. Letter to the General Administration. September 6, 1960. ArchivesAP, DDD 1 Archdiocese of Toronto.

Synod of Bishops, $7^{\text {th }}$ Ordinary General Assembly (October 1-30, 1987) (1987). The Synod Propositions. Origins. 1987:17. 502-503. 


\section{Reference works}

A Half Century: The Missionary Oblates of Mary Immaculate, Assumption Province in CanadaMisjonarze Oblaci Maryi Niepokalanej: Pót wieku Prowincji Wniebowzięcia NMP w Kanadzie. Ed. Janusz Błażejak. Toronto: The Missionary Oblates of Mary Immaculate-Assumption Province, 2006.

Błażejak, Janusz. „Współczesne zaangażowanie duszpasterskie Prowincji Wniebowzięcia NMP w Kanadzie." Polscy oblaci w stużbie Polonii kanadyjskiej. Eds. Wojciech Kluj and Jaroslaw Różański. [Studia i materiały misjologiczne, 13]. Pelplin: Wydawnictwo Bernardinum, 2007. 74-83.

Bouscaren, T. Lincoln. Ellis, Adam C. and Korth, Francis N. Canon Law: A Text and Commentary. $4^{\text {th }}$ revised edition. Milwaukee, WI: The Bruce Publishing Company, 1966.

Cicognani, Amleto G. "Letter to the bishops of the USA." February 17, 1938. CLD, vol. 2: 78-80.

Ciesluk, J. National Parishes in the United States. Washington, DC: The Catholic University of America, 1944.

Kalendarium Parafii Św. Jadwigi i Polonii w Oshawa - Events in the Life of St. Hedwig's Parish and the Polish Community in Oshawa. Compiled by Stanisław Poszwa. Oshawa [no publisher]. 1997.

Michalski, Maciej. „Powstanie i rozwój Prowincji Wniebowzięcia: Studium historyczne w świetle zasobu archiwalnego Archiwum Generalnego Misjonarzy Oblatów Maryi Niepokalanej w Rzymie.” Polscy oblaci w stużbie Polonii kanadyjskiej. Eds. Wojciech Kluj and Jaroslaw Różański. [Studia i materiały misjologiczne, 13]. Pelplin: Wydawnictwo Bernardinum, 2007. 55-73.

Our history. <http://demazenod.org/parish-structure/our-history/>. Accessed in August 2016.

Reczyńska, Anna. „Polonia kanadyjska: dzieje i problemy współczesne.” Polscy oblaci w shuzbbie Polonii kanadyjskiej. Eds. Wojciech Kluj and Jaroslaw Różański. [Studia i materiały misjologiczne, 13]. Pelplin: Wydawnictwo Bernardinum, 2007. 13-34.

Territorialità e personalità nel diritto canonico ed ecclesiastico: il diritto canonico di fronte al terzo millennio (Territoriality and Personality in Canon Law and Ecclesiastical Law: Canon Law Faces the Third Millennium). Proceedings of the $11^{\text {th }}$ International Congress of Canon Law and of the $15^{\text {th }}$ International Congress of the Society for the Law of the Eastern Churches, Budapest, 2-7 September 2001. Eds. Peter Erdö and Peter Szabó. Budapest: Szent István Társulat, 2002.

Wernz, Franciscus. Ius canonicum: Ad Codicis normam exactum opera P. Petri Vidal. Vol. 3: De religiosis, Rome: Apud Aedes Universitatis Gregorianæ, 1933.

Wiatrowski, Ralph E. "Establishment of a Parish That Is Both Territorial and Personal." CLSA Advisory Opinions 1994-2000. Ed. A.J. Espelage. Washington, DC: Canon Law Society of America, 2002. 132-133.

Wotum Polonii w Oshawie, [Toronto]; no date.

Kowal WoJciech, OMI. Born in Przeworsk on 19 April 1960. Entered the Missionary Oblates of Mary Immaculate in 1979; perpetually professed in 1984; ordained to the presbyterate in Obra, on 14 June 1986. Member of Assumption Province of the Missionary Oblates of Mary Immaculate in Canada (Toronto). University studies: Major Seminary of the Missionary Oblates of Mary Immaculate, Obra (M.Th., Pontifical Faculty of Theology, Poznań, 1986); Catholic University of Lublin (Master of Cosmology, 1991); Saint Paul University, Ottawa (J.C.L, 1994; J.C.D., 1998); University of Ottawa (M.C.L, 1994; Ph.D. [Canon Law], 1997). Advocate, Canadian Appeal Tribunal, Ottawa, 1995-1996; defender of the bond, Regina (SK) Regional Tribunal, 1997-1998; chancellor, archdiocese of Keewatin-Le Pas (MB), 1997-1998. Associate professor in the Faculty of Canon Law, Saint Paul University, Ottawa. 


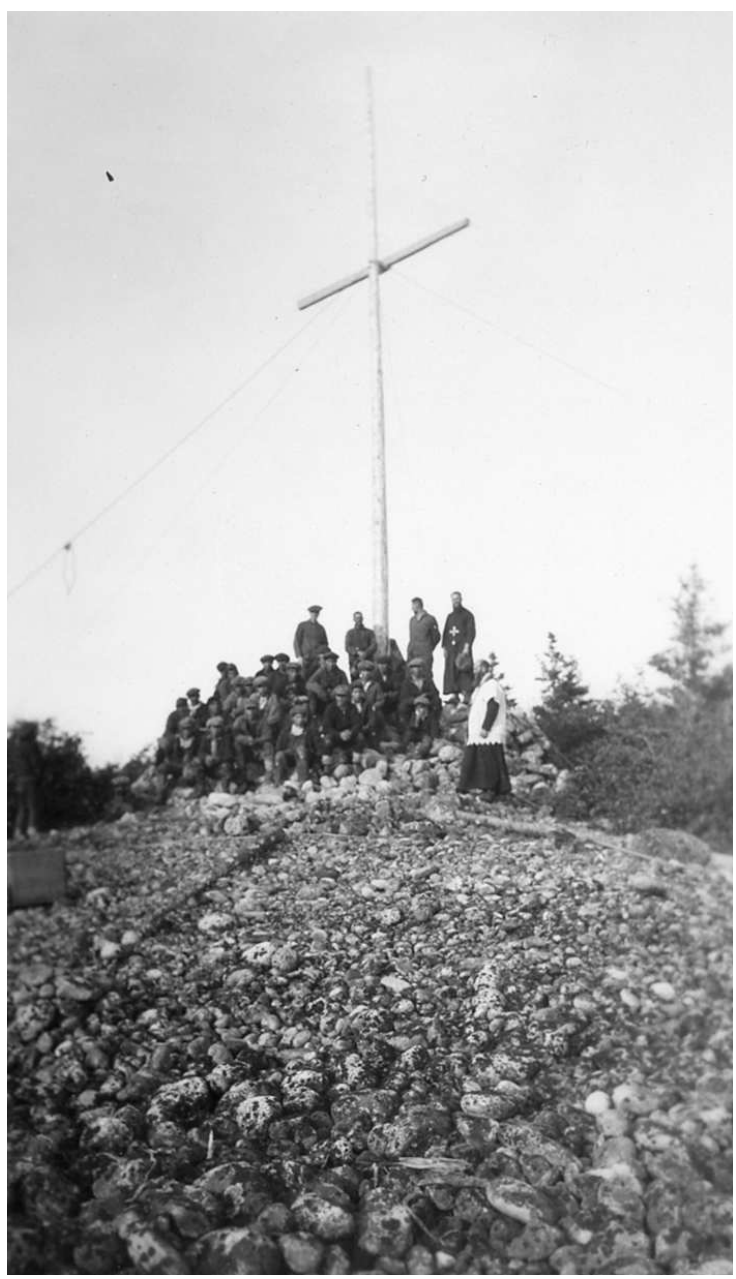

Vieux Comptoir - wrzesień 1938

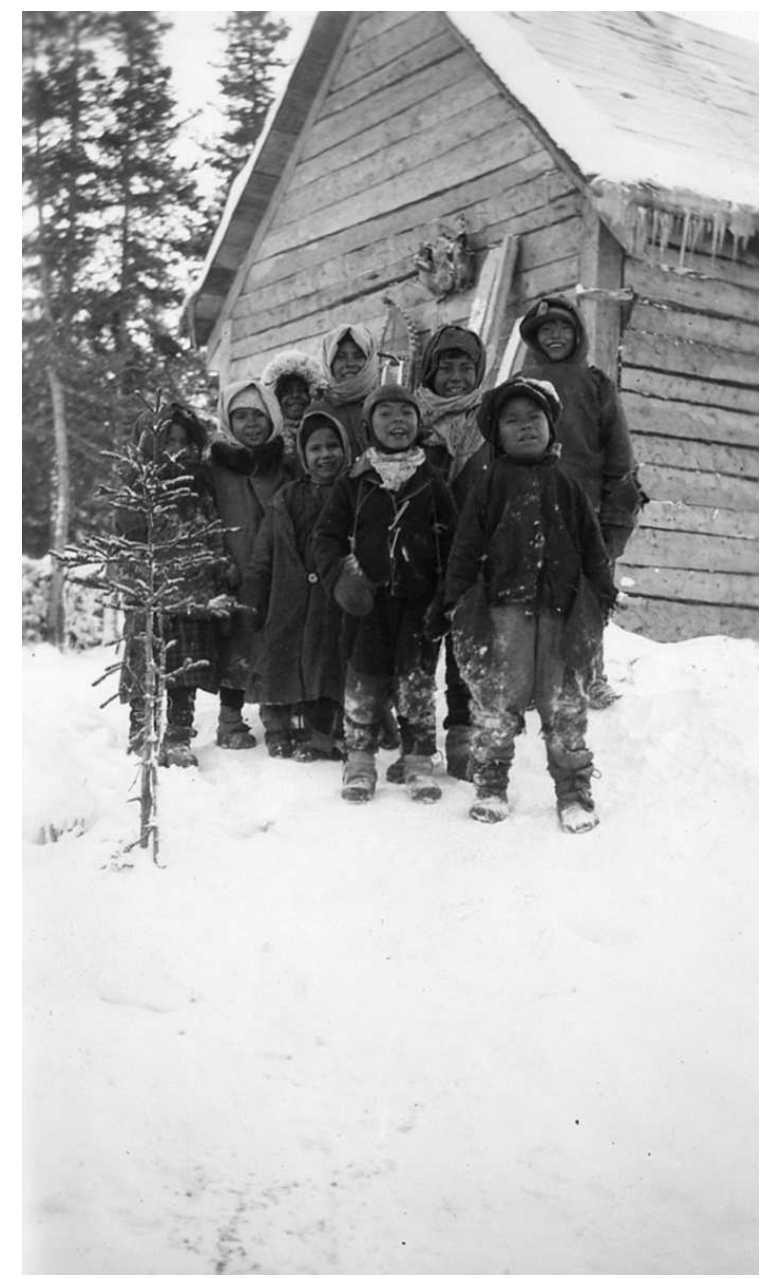

Vieux Comptoir - 1939 